\title{
Morfoanatomia de rizomas e raízes de Tillandsia L. (Bromeliaceae) dos Campos Gerais, PR, Brasil
}

\author{
Simone Segecin ${ }^{1,3}$ e Vera Lúcia Scatena ${ }^{2}$
}

Recebido em 12/11/2002. Aceito em 18/08/2003

\begin{abstract}
RESUMO - (Morfoanatomia de rizomas e raízes de Tillandsia L. (Bromeliaceae) dos Campos Gerais, PR, Brasil). Foi estudada a morfoanatomia dos rizomas e das raízes de Tillandsia crocata (E. Morren) Baker, T. gardneri Lindl., T. geminiflora Brongn., T. mallemontii Glaziou ex Mez., T. linearis Vell., T. lorentziana Griseb., T. recurvata L., T. stricta Soland. ex Sims., T. streptocarpa Baker, T. tenuifolia L. e Tillandsia sp., epífitas dos Campos Gerais, Paraná, Brasil. Os rizomas são horizontais, ou levemente inclinados e apresentam raízes intracorticais. São revestidos por epiderme unisseriada ou súber estratificado. O córtex parenquimático é constituído por células isodiamétricas, apresenta idioblastos de ráfides e grãos de amido. A endoderme é unisseriada, com células de paredes finas. O periciclo é uni ou multisseriado, com células de paredes finas ou espessadas. O cilindro vascular apresenta feixes vasculares colaterais. As raízes são adventícias intracorticais ou externas. Estas últimas apresentam velame multisseriado. $\mathrm{O}$ córtex apresenta idioblastos de ráfides e grandes espaços intercelulares na região interna. A exoderme apresenta duas a quatro camadas de células com paredes espessadas. A endoderme é unisseriada, com células de paredes finas ou espessadas. O periciclo é unisseriado, com células de paredes finas. O cilindro vascular é reduzido, poliarco. As raízes intracorticais diferem das externas por não apresentarem velame. A presença de rizoma com raízes intracorticais, raízes com velame, espaços intercelulares no córtex interno, idioblastos de ráfides e grande quantidade de células com paredes espessadas são caracteres anatômicos adaptativos, que provavelmente ocorrem como resposta ao hábito epifítico dessas plantas.
\end{abstract}

Palavras-chave: Tillandsia, morfologia, anatomia, rizomas, raízes

\begin{abstract}
Morphology and anatomy of rhizomes and roots in Tillandsia L. (Bromeliaceae) from the "Campos Gerais", PR, Brazil). Morphological and anatomical features of rhizomes and roots were studied in Tillandsia crocata (E. Morren) Baker, T. gardneri Lindl., T. geminiflora Brongn., T. mallemontii Glaziou ex Mez., T. linearis Vell., T. lorentziana Griseb., T. recurvata L., T. stricta Soland. ex Sims., T. streptocarpa Baker, T. tenuifolia L. and Tillandsia sp. They are epiphytes. The rhizomes are horizontal and present intracortical roots. They present uniseriated epidermis or storied cork; cortex with isodiametrical cells, idioblasts with raphide-sacs, and starch grains; uniseriated endodermis presenting thin-walled cells; uniseriated or multiseriated pericycle with thin or thick-walled cells; vascular cylinder presenting collateral vascular bundles. The adventitious roots are intracortical or external. The latter have multiseriated velamen; presenting idioblasts with raphide-sacs, cortical intercellular spaces, exodermis with thick-walled cells; uniseriated endodermis with thin or thick-walled cells; uniseriated pericycle with thin-walled cells; reduced vascular cylinder. The intracortical roots differ of the external ones for the lack of velamen. Most of these adaptative anatomical features might be related to the epiphytic habit of these plants.
\end{abstract}

Key words: Tillandsia, morphology, anatomy, rhizomes, roots

\section{Introdução}

Nos Campos Gerais do Paraná predomina a vegetação do tipo estepe gramíneo-lenhosa, que é interrompida por matas de Araucária encaixadas nos vales e cânions ou formando capões ou compondo matas ciliares. Nessa vegetação é comum a ocorrência de Bromeliaceae epífitas, bem como nos afloramentos rochosos. Nos Parques Estaduais de Vila Velha e do Guartelá, os afloramentos rochosos constituem os paredões que abrigam várias plantas, predominando Bromeliaceae, especialmente as
Tillandsia heliófitas (Veloso et al. 1991).

Bromeliaceae é predominantemente tropical e apresenta 51 gêneros com cerca de 1.520 espécies (Dahlgren et al. 1985). Segundo Stevens (2001), Tillandsia apresenta cerca de 550 espécies. De acordo com Madison (1977), as Bromeliaceae epífitas estão incluídas entre uma das três maiores famílias das monocotiledôneas epífitas; as outras duas são Araceae e Orchidaceae.

Atualmente Bromeliaceae encontra-se distribuída em três subfamílias: Pitcarnioideae, Tillandsioideae e Bromelioideae (Smith \& Downs 1974; 1979; Dahlgren

\footnotetext{
1 Rua República do Líbano 404, Jardim Carvalho, CEP 84015-710, Ponta Grossa, PR, Brasil. Bolsa CNPq

2 Departamento de Botânica, Instituto de Biociências - UNESP, C. Postal 199, Av. 24-A, 1515, Bela Vista, CEP 13506-900, Rio Claro, SP, Brasil. Bolsa CNPq

3 Autor para correspondência: rsmoro@uepg.br
} 
et al. 1985; Stevens 2001). A maioria das Tillandsioideae é epífita e ocorre em ambientes extremos, com adaptações especializadas nos órgãos vegetativos. Vivem em ambientes secos e possuem formas de crescimento altamente especializadas, incluindo sistema radicular reduzido, voltado principalmente à fixação da planta (De Paula 1998).

Na região dos Campos Gerais, no Paraná, encontram-se vários representantes de Bromeliaceae, sendo Tillandsia o gênero melhor representado, com doze espécies. Algumas delas podem ser consideradas exclusivas, pois habitam principalmente os afloramentos rochosos dos Campos Gerais, outras habitam matas ciliares e capões, sempre com hábito epifítico.

Estudos sobre anatomia de rizomas e raízes de Bromeliaceae foram realizados por Tomlinson (1969) e por Krauss (1948). Os autores não citaram a presença de velame nas raízes. Mais recentemente, Pita \& Menezes (2002) verificaram a presença de velame nas raízes terrestres de Dyckia e Encholirium e relacionaram sua presença com a adaptação dessas plantas ao hábitat xérico.

Dada a importância das Bromeliaceae no contexto dos Campos Gerais do Paraná este trabalho tem como objetivo estudar a morfoanatomia dos rizomas e das raízes das Tillandsia que lá ocorrem, visando sua caracterização anatômica e a interpretação das possíveis adaptações ao hábito epifítico.

\section{Material e métodos}

As Tillandsia foram coletadas na região dos Campos Gerais, PR nas áreas de preservação ambiental, Parques Estaduais de Vila Velha e Guartelá, e Parque Municipal São Jorge. As exsicatas estão depositadas nos herbários da Universidade Estadual de Ponta Grossa (HUEPG) e no Herbarium Rioclarense (HRCB), sob os números: Tillandsia crocata (E. Morren) Baker, HUEPG 4873, HRCB 27836; Tillandsia gardneri Lindl., HUEPG 4465, HRCB 33090; Tillandsia geminiflora Brongn., HUEPG 4876, HRCB 18836; Tillandsia linearis Vell., HUEPG 4874, HRCB 27832; Tillandsia lorentziana Griseb., HUEPG 4426, HRCB 30166; Tillandsia mallemontii Glaziou ex Mez., HUEPG 4390, HRCB 27833; Tillandsia recurvata L., HUEPG 4286, HRCB 27837; Tillandsia streptocarpa Baker, HUEPG 4420, HRCB 27829; Tillandsia stricta Soland. ex Sims., HUEPG 4238, HRCB 27835; Tillandsia tenuifolia L., HUEPG 4875, HRCB 27830; Tillandsia sp., HUEPG 3673.
O material coletado foi herborizado e fixado em FAA 50 (Johansen 1940) e posteriormente estocado em álcool etílico a 70\% para os estudos anatômicos. Para a análise anatômica, foram feitas secções, à mão livre com lâminas de barbear, na região apical dos rizomas e na região mediana das raízes externas, de pelo menos três indivíduos diferentes para cada espécie; as secções foram submetidas ao processo de dupla coloração com fucsina e azul de astra (Roeser 1962) e montadas em gelatina glicerinada.

Algumas secções de material fresco foram utilizadas para os testes microquímicos, empregando-se Lugol (Bücherl 1962) e Cloreto de Zinco Iodado (Strasburger 1911), para identificar o amido; Sudan III e Sudan IV (Johansen 1940), para lipídios; solução de Floroglucina em meio ácido (Johansen 1940) para lignina.

\section{Resultados}

As Tillandsia estudadas têm hábito epifítico e apresentam rizomas desde horizontais até levemente inclinados. Esses rizomas são envolvidos por bainhas de folhas velhas na região basal, folhas maduras na porção mediana e folhas jovens na apical (Fig. 1-4). As raízes adventícias externas saem da região basal do rizoma e aderem ao substrato.

Os rizomas de todas as espécies estudadas encaixam-se nos padrões anatômicos representados pelos diagramas de $T$. stricta (Fig. 5) e de T. linearis (Fig. 6), com três regiões distintas: epiderme ou súber estratificado, córtex e cilindro vascular. Idioblastos de ráfides estão presentes na região do córtex e do cilindro vascular, enquanto que as ráfides intracorticais localizam-se na periferia do cilindro vascular. Os feixes vasculares são colaterais e apresentam-se concentrados na região central do cilindro vascular (Fig. 5-6).

A epiderme da região apical do rizoma, em secção transversal, é unisseriada e possui células de paredes finas, em T. mallemontii (Fig. 7) e T. crocata (Fig. 11). Algumas espécies como T. gardneri (Fig. 9) e T. streptocarpa (Fig. 10) apresentam súber estratificado.

O córtex apresenta células parenquimáticas arredondadas, de paredes finas, maiores que as células do cilindro vascular. Idioblastos de ráfides ocorrem em todas as espécies estudadas e podem ser observados em T. mallemontii (Fig. 7-seta), em T. geminiflora (Fig. 8-setas), e em T. crocata (Fig. 11-seta) em que a célula aparece desprovida de conteúdo. A endoderme 

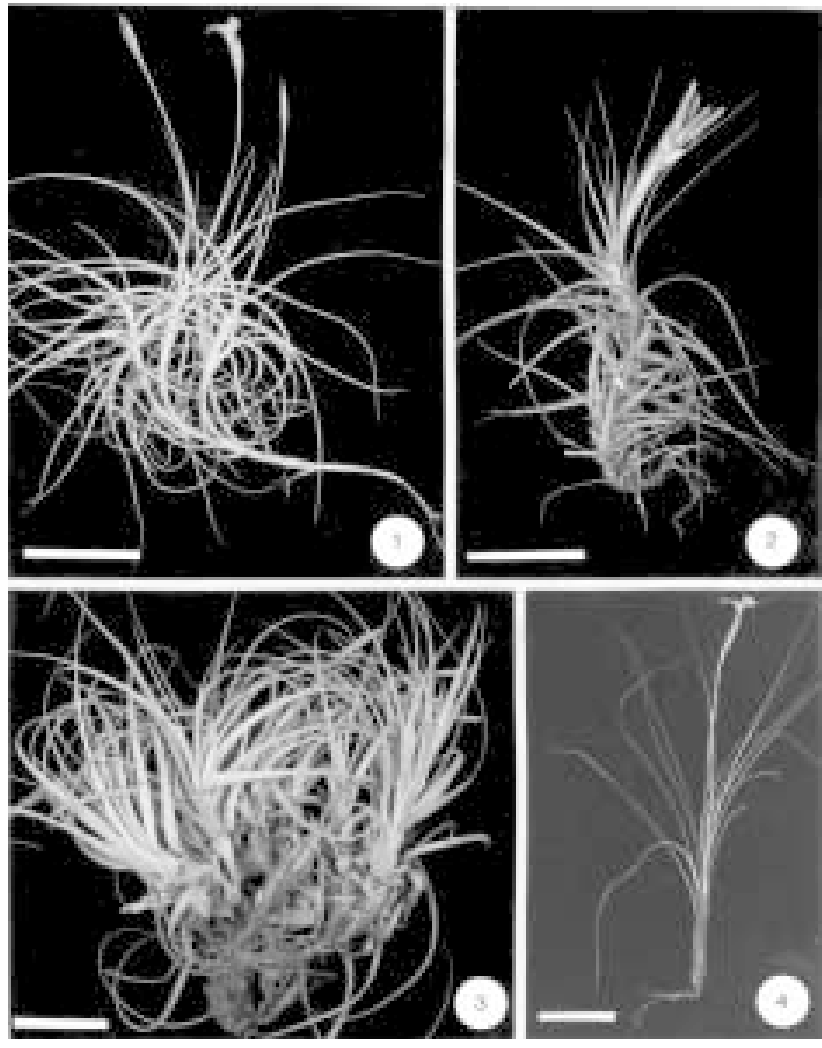

Figuras 1-4. Aspectos morfológicos de Tillandsia: 1. Tillandsia recurvata; 2. Tillandsia tenuifolia; 3. Tillandsia lorentziana ; 4. Tillandsia linearis (Barras: Fig. $1=4 \mathrm{~cm}$; Fig. $2=5 \mathrm{~cm}$; Fig. $3=7,5 \mathrm{~cm}$; Fig. $4=5 \mathrm{~cm}$ )

apresenta uma camada de células de paredes finas, menores em relação às demais células corticais, geralmente contendo grãos de amido, como pode ser observado em T. mallemontii (Fig. 7) e em T. crocata (Fig. 12).

O periciclo pode ser unisseriado, com células de paredes finas, como em T. mallemontii (Fig. 7), ou espessadas como em $T$. crocata (Fig.12), ou multisseriado com células de paredes espessadas, como em $T$. recurvata (Fig. 14). O cilindro vascular é constituído por feixes vasculares colaterais (Fig. 12, 14).

As raízes intracorticais (Fig. 13-seta, 15, 16) ocorrem nas regiões apical e mediana dos rizomas, o que pode ser observado quando secionadas transversalmente. As raízes intracorticais diferem das raízes externas pela ausência de velame. As raízes intracorticais apresentam epiderme unisseriada, exoderme composta por várias camadas de células e córtex mediano reduzido. Este é constituído de uma a duas camadas de células de paredes finas, como ocorre em T. streptocarpa (Fig. 15), ou células de paredes lignificadas, formando continuidade com a exoderme, sendo difícil sua diferenciação, como se observa em T. recurvata (Fig. 16). O córtex interno pode estar constituído de várias camadas de células com amplos espaços intercelulares, como em T. streptocarpa (Fig. 15), ou por uma única camada de células grandes, como em T. recurvata (Fig. 16). A endoderme (En) é unisseriada e apresenta células com espessamento de paredes em "U" (Fig. 15) ou "O" (Fig. 16). O periciclo é unisseriado (Fig. 15, 16). O cilindro vascular é reduzido, poliarco, formado por poucos elementos de xilema e floema; a medula é constituída de parênquima lignificado (Fig. 15-16).

As raízes adventícias externas de todas as espécies estudadas apresentam velame (Fig. 17-21). Tillandsia crocata, T. gardneri, T. geminiflora, T. linearis, $T$. streptocarpa, $T$. stricta e $T$. recurvata apresentam velame cujas células possuem paredes finas, forma variável, desde arredondadas até irregulares como observado em $T$. recurvata (Fig. 18).
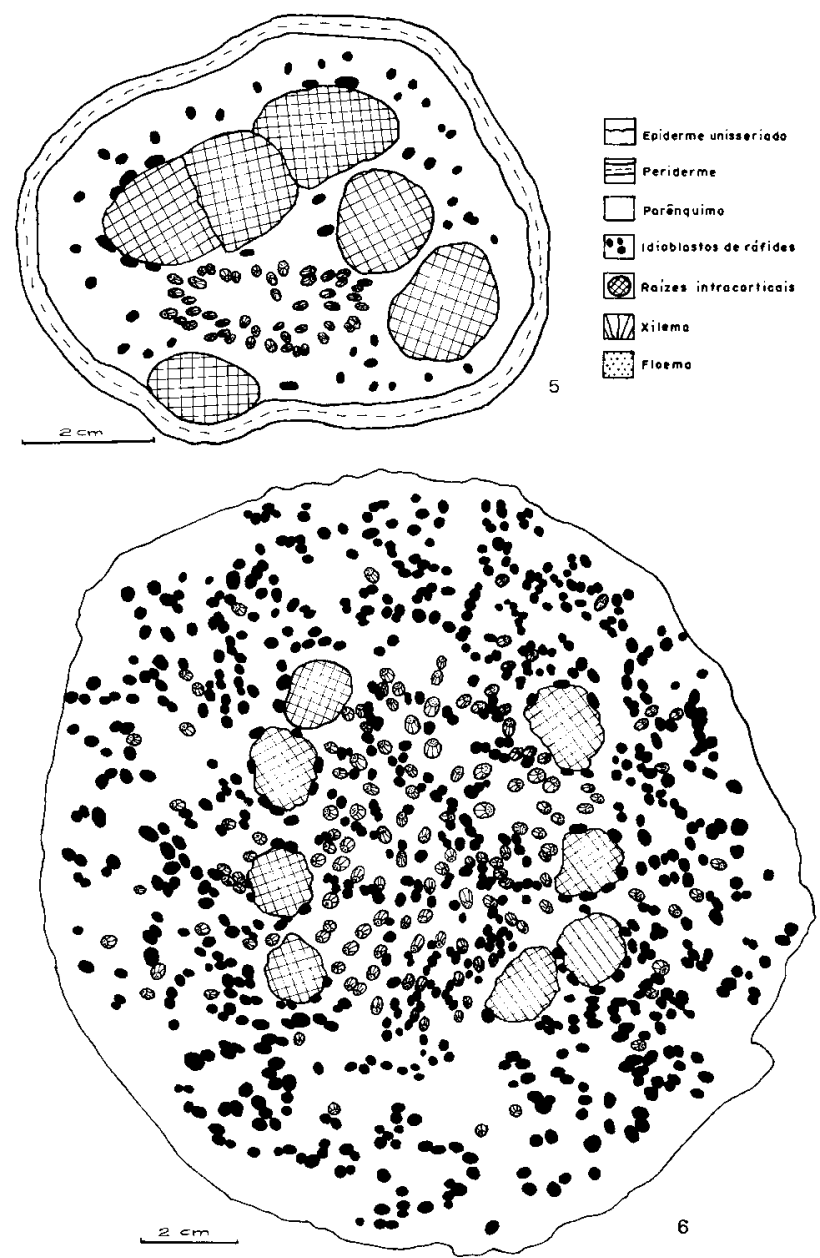

Figuras 5-6. Diagramas de secções transversais da região apical dos rizomas de Tillandsia: 5. Tillandsia linearis. 6. Tillandsia stricta. 
As demais espécies estudadas apresentam raízes com velame constituído de células de paredes espessadas, como pode ser observado em T. geminiflora (Fig. 19) e em T. mallemontii (Fig. 20). O número de camadas de células do velame é variável para as espécies (Fig. 17-20). A camada periférica do velame pode estar diferenciada em epivelame, como pode ser observado em T. linearis (Fig. 17). Em Tillandsia sp. observou-se a ocorrência de pêlos radiculares unicelulares na camada mais periférica do epivelame (Fig. 21-seta).

$\mathrm{O}$ córtex das raízes é diferenciado em externo, mediano e interno. O córtex externo é a exoderme, que é multisseriada, formada por células de paredes espessadas, hexagonais (Fig. 17-20). Algumas espécies apresentam idioblastos de ráfides também na exoderme, como pode ser observado em T. mallemontii
(Fig. 20-seta). O córtex mediano é constituído por células de paredes finas, com número variado de camadas de células hexagonais (Fig. 17-20). O córtex interno apresenta células parenquimáticas maiores em relação às células do córtex mediano, são arredondadas, geralmente apresentam grãos de amido; nesta região ocorrem grandes espaços intercelulares (Fig. 17-20). A endoderme é unisseriada com células de paredes finas, sem evidência de estrias de Caspary, como em T. linearis (Fig. 17) e T. recurvata (Fig. 18), ou espessadas, como em T. geminiflora (Fig. 19) e T. mallemontii (Fig. 20). O periciclo é unisseriado, com células de paredes finas (Fig. 17-20).

O cilindro vascular apresenta estrutura poliarca, é formado por elementos de xilema e floema. A medula é constituída de parênquima lignificado (Fig. 17-20).

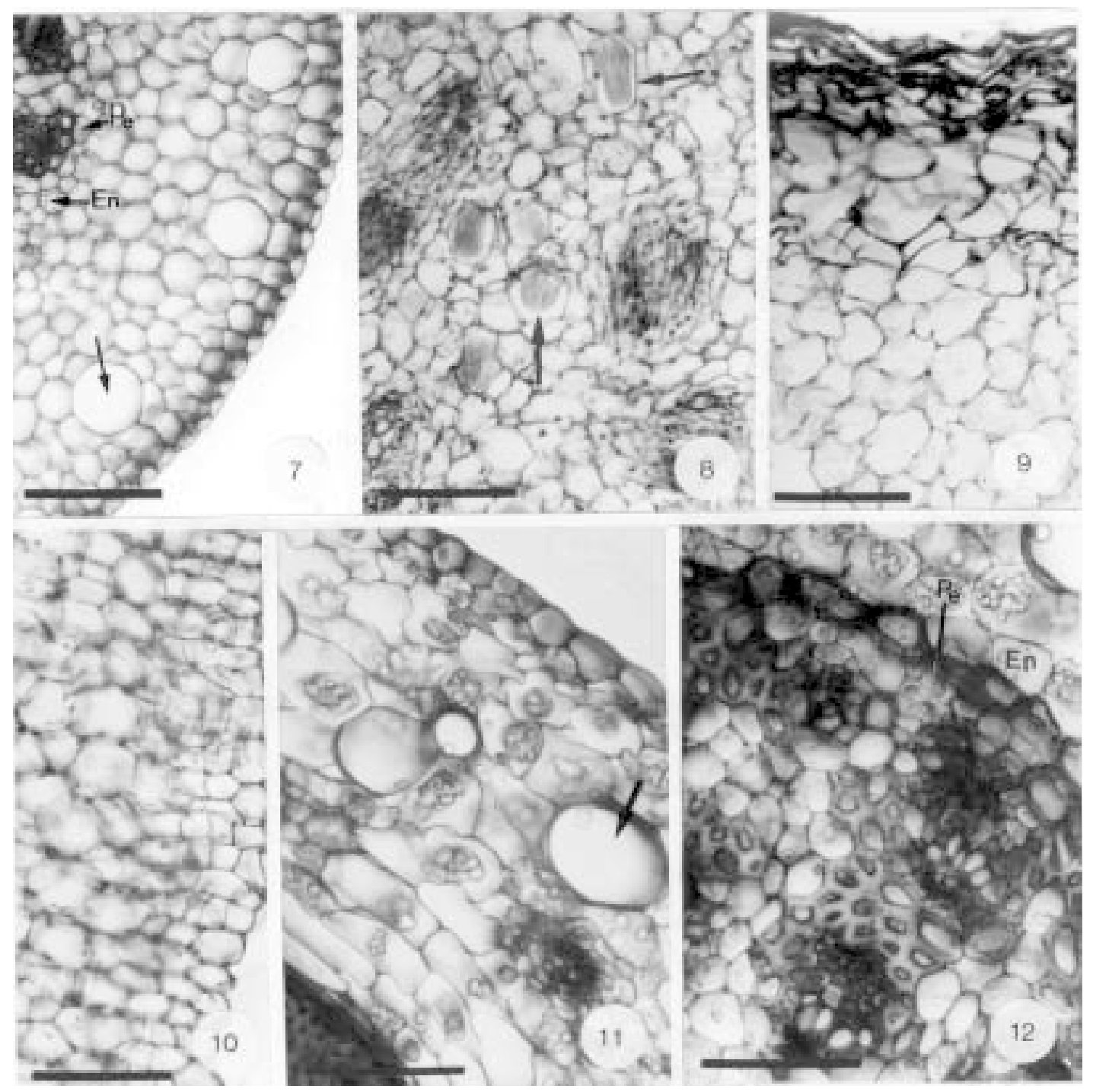

Figuras 7-12. Aspectos anatômicos de secções transversais da região apical dos rizomas de Tillandsia: 7. Tillandsia mallemontii. 8. Tillandsia geminiflora. 9. Tillandsia gardneri. 10. Tillandsia streptocarpa. $11-12$. Tillandsia crocata $.($ Barras $=100 \mu \mathrm{m}) .($ En $)$ endoderme, (Pe) periciclo, setas $=$ idioblasto de ráfides. 


\section{Discussão}

Todas as Tillandsia estudadas neste trabalho, ocorrentes nos Campos Gerais do Paraná, apresentam rizomas com raízes intracorticais. Essa característica também foi observada para outras espécies de Bromeliaceae por Chodat \& Vischer (1916) e Tomlinson (1969), em que os autores relacionaram a presença dessas raízes intracorticais com a sustentação dessas plantas. Concorda-se aqui com a interpretação desses autores, uma vez que a ocorrência de raízes intracorticais nas Tillandsia estudadas deve auxiliar na sustentação dessas plantas que são epífitas de rochas e/ou troncos de árvores.

Pita \& Menezes (2002) citaram para Dyckia e Encholirium, a presença de caule com tecido protetor, que constitui súber estratificado de origem parenquimática. Nas Tillandsia estudadas, algumas delas apresentam rizoma com súber, que deve estar relacionado com a proteção mecânica, evitando o atrito do órgão com o substrato. A maioria das espécies estudadas apresenta a parte mais antiga dos rizomas recoberta por bainhas de folhas velhas, estruturas que também aumentam a proteção mecânica e podem atuar na redução da transpiração, funcionando como isolante térmico.

As Tillandsia aqui estudadas apresentam amido no rizoma, principalmente na região cortical. Segundo Holttum (1955), o amido armazenado no rizoma de muitas plantas é utilizado como reserva para o crescimento, sendo consumido na propagação vegetativa. $\mathrm{O}$ fato das Tillandsia apresentarem rizoma

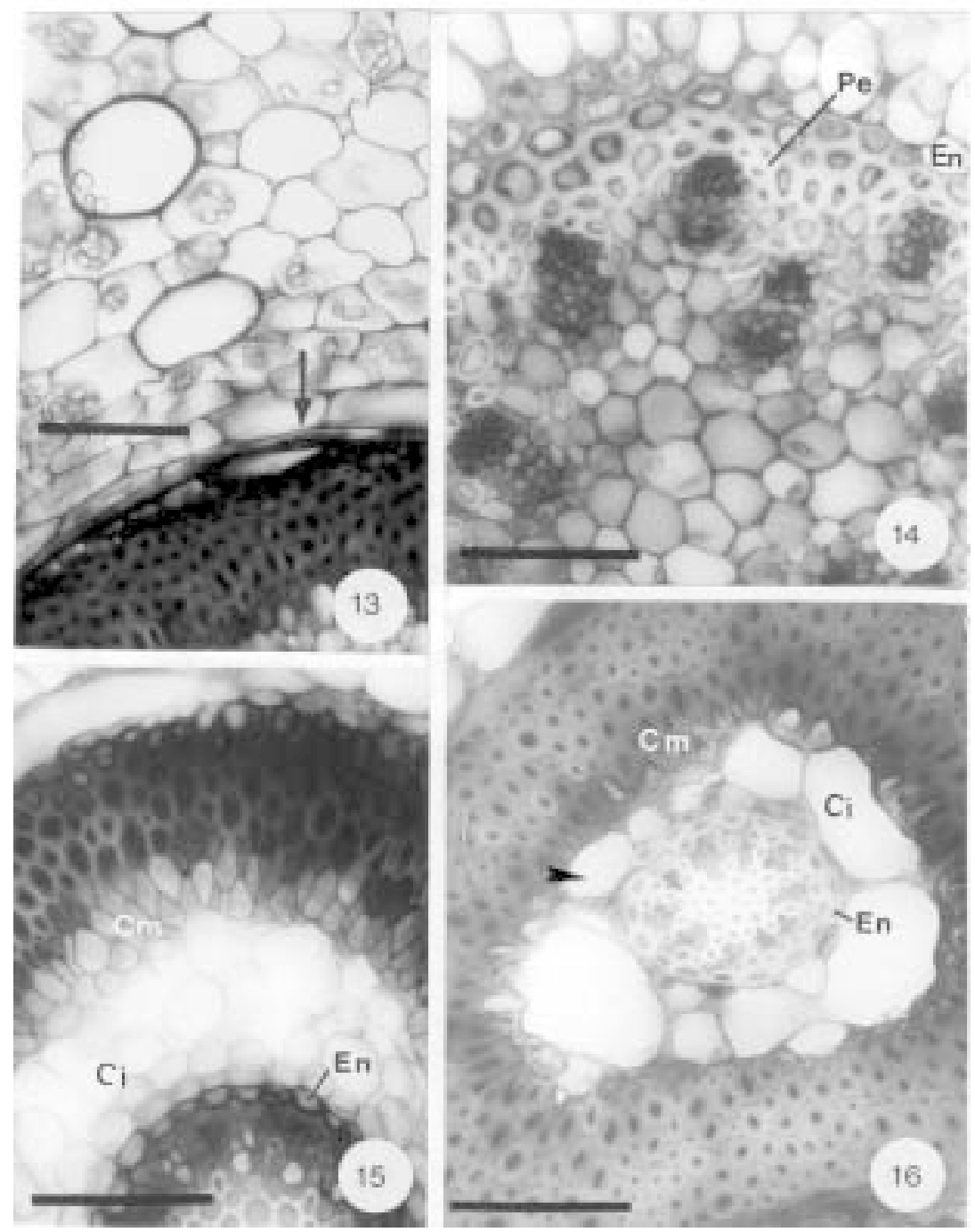

Figuras 13-16. Aspectos anatômicos de secções transversais da região apical dos rizomas de Tillandsia com raízes intracorticais: 13. Tillandsia tenuifolia: raiz intracortical (seta). 14. Tillandsia recurvata: cilindro vascular. 15. Tillandsia streptocarpa: raiz intracortical.

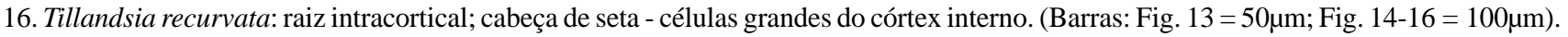
(Ci) córtex interno, $(\mathrm{Cm})$ córtex mediano, $(\mathrm{En})$ endoderme, $(\mathrm{Pe})$ periciclo. 
e possuírem hábito epifítico, sugere que a propagação vegetativa é importante na manutenção de suas populações e que a mesma é garantida pela presença de amido no rizoma.

Tomlinson (1969) descreveu para as Bromeliaceae epífitas a presença de raízes adventícias com a função exclusiva de fixar a planta ao substrato. Nas Tillandsia estudadas observou-se a presença de velame, que além de exercer papel protetor, também desempenha a função de absorver água. Dessa forma, essas raízes exercem a função de fixação, suporte e absorção, características essas que devem estar relacionadas ao hábito epifítico das espécies.

Possivelmente Tomlinson (1969), copilando dados de outros autores que estudaram a anatomia de Bromeliaceae, generalizou o aspecto estrutural das raízes adventícias. Em Dyckia e Encholirium, ambas terres- tres, Pita \& Menezes (2002) constataram a presença de velame, comprovando que esse pode ocorrer tanto em espécies terrestres de Bromeliaceae como nas epífitas.

De acordo com Dycus \& Knudson (1957), o velame exerce a função de proteção mecânica, além de impedir a perda de água pelo córtex. Outros autores, como Pridgeon (1982) e Mauseth (1988), afirmaram que o velame exerce também a função de armazenamento de água nas orquídeas por eles estudadas. Concordando com estes autores, pode-se atribuir ao velame presente nas raízes das Tillandsia estudadas neste trabalho, tanto a função de armazenamento de água e sais minerais nela diluídos, como de proteção mecânica, e ainda, a de evitar a transpiração excessiva, funções que auxiliam a sobrevivência dessas plantas em ambientes extremos

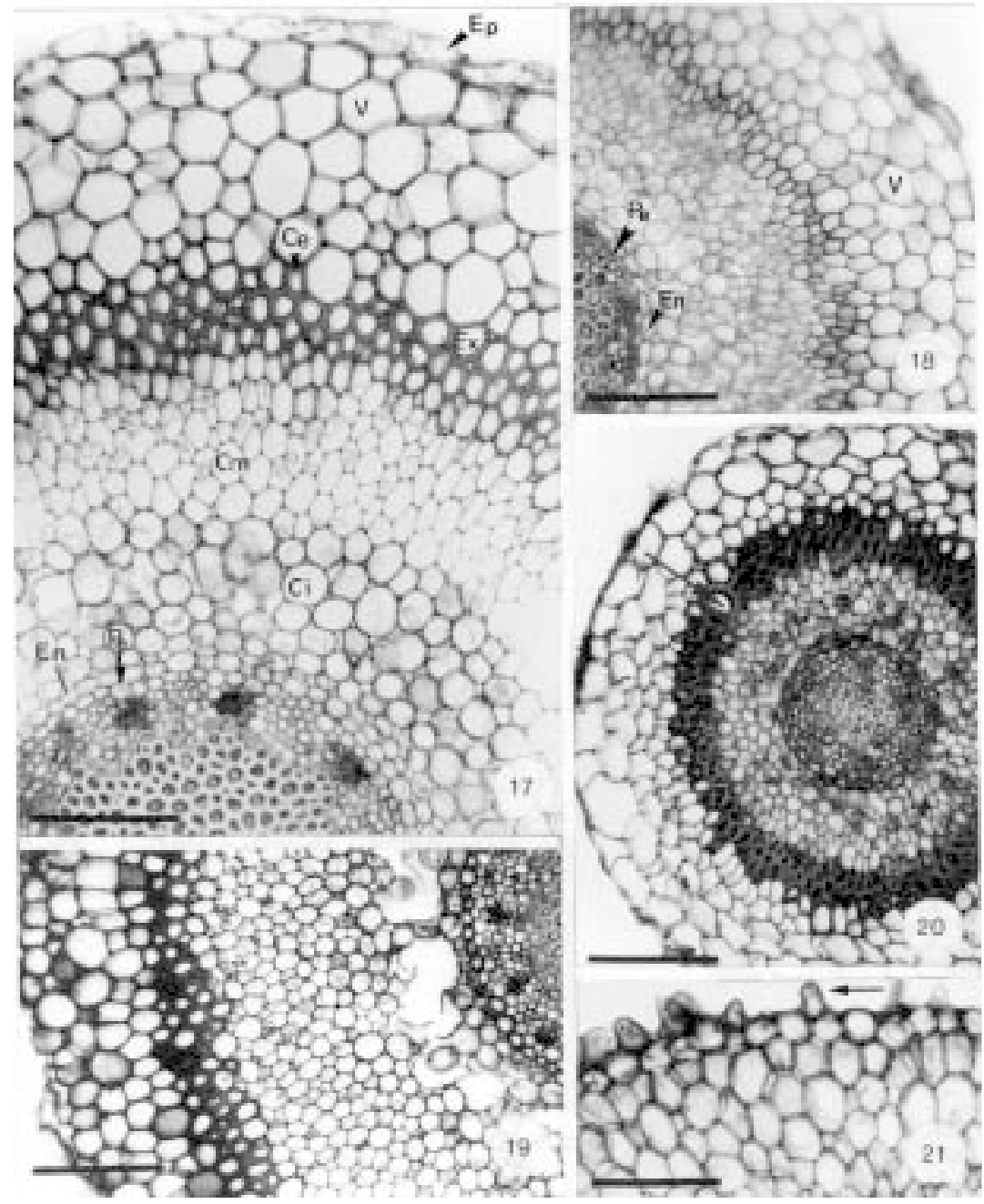

Figuras 17-21. Aspectos anatômicos de secções transversais da região mediana das raízes de Tillandsia: 17. Tillandsia linearis. 18. Tillandsia recurvata. 19. Tillandsia geminiflora. 20. Tillandsia mallemontii exoderme (seta). 21. Tillandsia sp. pêlo radicular (seta). (Barras $=100 \mu m)$. $(\mathrm{Ce})$ córtex externo, $(\mathrm{Ci})$ córtex interno, $(\mathrm{Cm})$ córtex mediano, $(\mathrm{En})$ endoderme, $(\mathrm{Ep})$ epivelame, $(\mathrm{Ex})$ exoderme, $(\mathrm{Pe})$ periciclo, $(\mathrm{V})$ velame). 
de insolação, escassez de água, ventos constantes e atritos com o substrato.

Segundo Engard (1944), sob condições ambientais especiais, a camada externa do velame pode desenvolver pêlos radiculares. A presença de pêlos radiculares também foi observada em raízes de orquídeas (Dycus \& Knudson 1957; Benzing et al. 1983; Sandford \& Adanlawo 1973) e de bromélias Dyckia e Encholirium (Pita \& Menezes 2002). Entre as Tillandsia estudadas observou-se que Tillandsia sp. (Fig. 21) apresenta pêlos radiculares evidentes, cuja presença deve estar relacionada às condições ambientais e ao hábito da espécie, que é rupícola e fica exposta à insolação direta e ventos constantes, em locais onde o escoamento de água da chuva é rápido. Essa característica anatômica deve ser interpretada como estratégia da espécie para aumentar a superfície de absorção de água.

Sandford \& Adanlawo (1973) verificaram em Orchidaceae que as condições ambientais, como a disponibilidade de água e a alteração da temperatura, podem modificar a estrutura anatômica da raiz, especialmente no que se refere ao tamanho e ao espessamento das células do velame. Os autores concluem que, em Orchidaceae de ambientes secos, o velame apresenta-se com numerosas camadas de células espessadas, enquanto que nas espécies de ambientes úmidos o velame apresenta-se com menor número de camadas de células, e estas, com paredes finas.

Nas Tillandsia aqui estudadas, tanto as que crescem em ambientes expostos, secos (rupícolas), como as de ambientes mais úmidos (matas ciliares), apresentam mais ou menos o mesmo número de camadas de células de velame e o espessamento de suas paredes é variável, independentemente das condições do ambiente. Por exemplo, T. streptocarpa, que é rupícola, cresce em ambientes expostos, apresenta três a cinco camadas de células no velame, com paredes celulares finas; enquanto T. tenuifolia e T. linearis, epífitas de matas ciliares, que crescem onde a umidade é maior e a insolação é menor, apresentam velame com maior número de camadas de células e suas paredes são espessadas. Talvez a presença de velame, característica anatômica presente em todas as Tillandsia estudadas, seja um caráter diagnóstico para esse grupo de plantas.

As Tillandsia estudadas apresentam idioblastos de ráfides localizados tanto nos rizomas como nas raízes. Segundo Costa (1975), em muitas monocotiledôneas, o ácido oxálico ocorre na forma de cristais de oxalato de cálcio insolúvel, apresentando-se de formas diversas. De acordo com Fahn \& Cutler (1992), a presença de idioblastos de ráfides é considerada adaptação das plantas às condições xerofíticas. Prychid \& Rudall (2000) também fizeram referência aos cristais aciculares na prevenção contra ataque de herbívoros.

Verificou-se nas Tillandsia estudadas que as raízes intracorticais diferenciam-se das raízes externas por não apresentarem velame. Ambas apresentam espaços intercelulares no córtex interno. De acordo com Meyer (apud Tomlinson 1969) os espaços intercelulares presentes no córtex interno das raízes de Bromeliaceae têm a função de transportar a água por capilaridade através desses espaços. Considerando que as Tillandsia estudadas neste trabalho são epífitas atmosféricas e vivem sob constante estresse hídrico, talvez se possa relacionar a função desses espaços intercelulares com o transporte de água por capilaridade, constituindo assim, uma estratégia eficiente para transportar a água mais rapidamente e aproveitar melhor a sua disponíbiidade

Em ambos os tipos de raízes, nas intracorticais e nas externas, a estrutura do cilindro vascular é semelhante e apresentam medula constituída de células parenquimáticas totalmente lignificadas. A exoderme das raízes intracorticais geralmente é muito mais lignificada do que a das raízes externas, conferindo maior rigidez e sugerindo que essas raízes intracorticais auxiliam na sustentação dessas plantas epífitas.

As características estruturais dos rizomas e das raízes das Tillandsia estudadas, como: presença de raízes intracorticais nos rizomas, raízes com velame, córtex diferenciado, presença de idioblastos de ráfides, espaços intercelulares no córtex interno, medula parenquimática lignificada e grande quantidade de células com paredes espessadas, poderão auxiliar a melhor compreensão das adaptações estruturais, como estratégia de sobrevivência dessas plantas às condições ambientais especiais, peculiares do hábito epifítico.

\section{Referências bibliográficas}

Benzing, D.H.; Friedman, W.E.; Peterson, G. \& Renfrow, A. 1983. Shootlesness, velamentous roots, and the preeminence of Orchidaceae in the epiphytic biotope. American Journal of Botany 70: 121-133.

Bücherl, W. 1962. Técnica microscópica. Polígono, São Paulo.

Chodat, R. \& Vischer, W. 1916. Résultats scientifiques de une mission botanique suisse au Paraguay IV. Broméliacées. Bulletin Société Botanique Genève 8: 83-160, 186-264. 
Costa A.F. 1975. Farmacognosia. Fund. Calouste Gulbenkian, Lisboa.

Dahlgren, R.M.T.; Clifford, H.T. \& Yeo, P.F. 1985. The families of the monocotyledons study. Academic Press, London.

De Paula, C.C. 1998. Cultivo de bromélias para fins comerciais ou hobby. CPT, Viçosa.

Dycus, A.M. \& Knudson, L. 1957. The role of the velamen of the aerial roots of orchids. Botanical Gazette 119: 78-87.

Engard, C.J. 1944. Morfological identity of the velamen and exodermis in orchids. Botanical Gazette 105: 457-462.

Fahn, A. \& Cutler, D.F. 1992. Xerophytes. Encyclopedia of plant taxonomy. Gebrüder Borntraeger, Berlin.

Holttum, R. 1955. Growth habitats of monocotyledons variations on a theme. Phytomorphology 5: 399-413.

Johansen, D.A. 1940. Plant microtechinique. MacGraw-Hill, New York.

Krauss, B.H. 1948. Anatomy of the vegetative organs of the Pineapple, Annanas comosus (L.) Merr. Botanical Gazette 110: 159-217.

Madison, M. 1977. Vascular epyphytes: their systematic occurence and salient features. Selbyana 2(1): 1-13.

Mauseth, J.D. 1988. Plant anatomy. Benjamin/Cummings Publishing Company, Inc, California.

Pita, P.B. \& Menezes, N.L. 2002. Anatomia da raiz de espécies de Dyckia Schult. F. e Encholirium Mart. ex Schult. \& Schult. f. (Bromeliaceae, Pitcairnioideae) da Serra do Cipó (Minas Gerais, Brasil), com especial referência ao velame. Revista Brasileira de Botânica 25(1): 25-34.

Pridgeon, A.M. 1982. Diagnostic anatomical characteres in the Pleurothallidinae (Orchidaceae). American Journal of Botany 69(6): 921-938.
Prychid, C.J. \& Rudall, P.J. 2000. Distribution of calcium oxalate crystals in monocotyledons. In: K.L. Wilson \& D.A. Morrison (eds.). Monocots: Systematics and Evolution. Csiro Publishing, Australia.

Roeser, K.R. 1962. Die Nadel der SchwarzkieferMasenprodukt und Keinstwert der Natur. Microkosmos 61(2): 33-36.

Sandford, W.W. \& Adanlawo, I. 1973. Velamen and exodermis characters of West African epiphytic orchids in relation to taxonomic grouping and habitat tolerance. Botanical Journal of the Linnean Society 66: 307-321.

Smith, L.B. \& Downs, R.J. 1974. Pitcairnioideae (Bromeliaceae). Flora Neotropica, Monographs 4(1): 1-658.

Smith, L.B. \& Downs, R.J. 1979. Bromelioideae (Bromeliaceae). Flora Neotropica, Monographs 14(3): 1604-1724.

Stevens, P.F. 2001 onwards. Angiosperm Phylogeny Website. Version 3, May 2002. http://www.mobot.org/ MOBOT/research/Apweb/.

Strasburger, E. 1911. Handbook of practical botany. George Allen \& Company Ltda, London.

Tomlinson, P.B. 1969. III - Commelinales-Zingiberales. In: C.R. Metcalfe (ed.). Anatomy of the Monocotyledons. Clarendon Press, Oxford.

Veloso, H.P.; Rangel Filho, A.L. \& Lima, J.C.A. 1991. Classificação da vegetação brasileira adaptada a um sistema universal. IBGE, Rio de Janeiro. 